\title{
Systematic Review and Meta-Analysis of Acupuncture for Pain Management in Women Undergoing Transvaginal Oocyte Retrieval
}

\author{
Li-Ying Liu' ${ }^{1} *$ \\ Zi-Lei Tian',* \\ Fu-Ting Zhu' \\ Han Yang' \\ Fang Xiao' \\ Rong-Rong Wang' \\ Ling Chen' \\ Zhi-Yong Xiao' \\ Si-Yi Yul \\ Fan-Rong Liang' \\ Wen-Hui Hu${ }^{2}$ \\ Jie Yang ${ }^{1,2}$
}

'Acupuncture and Tuina School, Chengdu University of Traditional Chinese Medicine, Chengdu, Sichuan Province, People's Republic of China; ${ }^{2}$ Clinical Research Center for Acupuncture and Moxibustion in Sichuan province, Chengdu Xinan Gynecological Hospital, Chengdu, Sichuan Province, People's Republic of China

*These authors contributed equally to this work

\begin{abstract}
Objective: To obtain evidence-based conclusions about the effect of acupuncture on pain relief in women undergoing oocyte retrieval, the results of randomized controlled trials (RCTs) that met the criteria were assessed on the Pain Assessment Scale and pregnancy indicators.
\end{abstract}

Search Methods: References were retrieved in MEDLINE, EMBASE, CNKI database, CBM database, VIP database, and Wanfang database from inception to June 26, 2021. Unpublished ongoing trials were searched in the Clinical Trials Registries. This review included RCTs that investigated the acupuncture analgesic effects during oocyte retrieval in women undergoing in vitro fertilization.

Results: Fourteen RCTs (2503 women in total) with six types of comparisons were finally included. The quality of concluding evidence was generally low or very low. Performance bias and outcome assessment bias was the main risk of bias of the included studies. Acupuncture combined with conscious sedation and analgesia (CSA) was associated with less intraoperative $(\mathrm{SMD}=-1.03 ; 95 \% \mathrm{CI}:-1.71$ to -0.36$)$ and postoperative $(\mathrm{SMD}=-1.11$; 95\% CI: -1.51 to -0.71 ) pain compared to receive CSA alone in oocyte retrieval. Acupuncture with non-steroidal anti-inflammatory drugs (NSAIDs) was more effective than using NSAIDs alone for postoperative analgesia $(\mathrm{MD}=-1.76 ; 95 \% \mathrm{CI}$ : -2.08 to $-1.44)$.

Conclusion: Acupuncture complex analgesic therapy is more effective than utilizing CSA or NSAIDs alone. Furthermore, there is no significant consensus on whether there is an analgesic effect of applying acupuncture alone during oocyte retrievals, which needs further research. The overall results should be interpreted with caution due to the high risk of bias/ low-GRADE scores among these studies.

Protocol and Registration: PROSPERO registration number: CRD42020170095.

Keywords: acupuncture, analgesia, oocyte retrieval, meta-analysis, systematic review

\section{Introduction}

Oocytes pick-up (OPU) through the vagina under ultrasound guidance is a frequently performed outpatient procedure during assisted reproductive technology (ART). Anesthesia is still integral in this procedure which relieved repeated pain and negative emotions in women undergoing in vitro fertilization (IVF). Among the standard methods of analgesia, the need for general anesthesia (GA) declines with less-invasive oocyte retrieval techniques, and paracervical block (PCB) cannot meet a woman's anesthesia minimum needs. ${ }^{1}$ Thus, conscious
No. 37 Shi'er Qiao Road, Chengdu,

Sichuan, 610023, People's Republic of

China

Tel +86 I38 822967|4

Email jenny_yang_jie@I26.com

Wen-Hui Hu

No. 66 Bisheng Road, Chengdu, Sichuan,

610023, People's Republic of China

Tel +86 I3056699956

Email642926505@qq.com 
sedation and analgesia (CSA) are the most common and acceptable anesthesia methods with a high degree of satisfaction. $^{2}$ These pharmacological anesthetics provide immediate analgesia and are widely used in clinical practice. However, studies have found that anesthetic drugs penetrate the follicular fluid and negatively affect oocyte fertilization and embryo growth. ${ }^{3-5}$ There are definite needs to investigate non-pharmacological analgesia to reduce side effects and adverse events undergoing IVF.

Acupuncture has been widely used during long periods for analgesia. ${ }^{6,7}$ Prolonged clinical practice proved acupuncture compound analgesia therapy in OPU has the advantages of safety, high efficiency, fast recovery, and few side effects. ${ }^{8,9}$ Although previous systematic review ${ }^{10}$ demonstrated no evidence supporting acupuncture to be more optimal for pain relief during OPU than PCA with CSA, the updated Cochrane review supported acupuncture is appropriate to adjuvant analgesia OPU process. Various analgesic combinations are the current trend in OPU and are hotspots of peer attention. Therefore, acupuncture analgesia during OPU as non-pharmacological and desirable solutions needs to be evaluated comprehensively and systematically.

This review would include randomized controlled trials (RCTs) on acupuncture for pain relief during OPU to conduct a systematic review and meta-analysis of the relevant studies. It aimed to evaluate acupuncture for pain relief during OPU in an evidence-based perspective and provided recommendations for acupuncture clinical analgesia.

\section{Materials and Methods}

The review was registered at PROSPERO. All contents and report details were strictly referred to Preferred Reporting Items for Systematic Reviews and Metaanalyses (PRISMA). ${ }^{11}$

\section{Search Strategy}

Both English and Chinese publications of six databases, including PubMed, EMBASE, Chinese National Knowledge Infrastructure (CNKI), VIP Database, Chinese Biomedical Literature (CBM) Database, and WanFang Database, were searched electronically from inception to June 26, 2021. The search strategy included the medical subject headings (MeSH) terms in combination with free words. It was adjusted according to different databases. The searched MeSH terms were as follows: Fertilization in Vitro; Sperm Injections, Intracytoplasmic;
Ovarian Follicle; Oocyte Donation; Oocyte Retrieval; Analgesia; Acupuncture; Acupuncture Therapy; Electroacupuncture; Moxibustion; Acupuncture Analgesia; Transcutaneous Electric Nerve Stimulation; Acupressure. The unpublished ongoing trials were searched in clinical trial registries through the World Health Organization (WHO) International Clinical Trial Registry Platform, Cochrane Central Register of Controlled Trials, and ClinicalTrials.gov, Chinese Clinical Trial Register. Besides, retrieved RCTs of published reviews were manually searched. The exact search strategies were shown in Supplementary Enclosure.

\section{Inclusion Criteria}

RCTs that evaluated the efficacy of acupuncture analgesia for women undergoing transvaginal oocyte retrieval (as part of IVF) were included in the study. In a broad sense, acupuncture therapies included auricular acupuncture, electroacupuncture, manual acupuncture, transcutaneous electrical acupoint stimulation (TEAS). There was no restriction on intervention duration for acupuncture treatment, but it should be recorded in detail. Drug analgesia (such as sedatives, non-steroidal anti-inflammatory drugs, etc), invasive sham acupuncture (such as shallow sting), non-invasive placebo acupuncture, as well as treatment in the control group were accepted. Studies with different types of acupuncture in the control group were excluded.

Primary outcome indicators were subjective pain assessment scale such as the simplified McGill pain questionnaire (SF-MPQ), ${ }^{12}$ visual analog scale (VAS), ${ }^{13}$ and WHO pain rating scale. Both the VAS and WHO pain scores are simple self-rating scales. The VAS is a scale consisting of vertically oriented $10 \mathrm{~cm}$ lines on paper representing pain from mild to severe $(0-10$ or $0-100$ points). WHO pain scores were likely to be a numerical rating scale from 0 to 12 , representing pain levels from mild to severe. SF-MPQ includes present pain intensity (PPI), pain rating index (PRI), and VAS. The PRI consists of 11 sensory phrases and four affective phrases to describe pain. For all phrases describing pain, " 0 " indicates no pain, "1" indicates mild pain, " 2 " indicates moderate pain, and " 3 " indicates severe pain. A score from 0 to 5 was used to indicate the PPI from no pain to extreme pain.

Secondary outcome indicators were pregnancy-related (such as the number of oocytes retrieved, clinical pregnancy rate, high-quality embryo rate, etc.) and surgery- 
related indicators (such as adverse reactions, emotion evaluation, etc.).

\section{Study Selection}

Study selections and data management were made by two reviewers (RRW and LC). We first screened the titles and abstracts. Then the entire content was downloaded, and the decision to include the study was made. Finally, the disagreement between RRW and LC regarding the selection was resolved by LYL. The retrieved literature with detailed information of the selected studies was imported into Excel.

\section{Quality Assessment}

Two reviewers (RRW and LC) used the Cochrane Handbook of Systematic Reviews ${ }^{14}$ to assess the risk of bias for each included trial. The risk of bias for the assessment category consisted of seven items. Each item was classified into three levels: low risk, unclear risk, and high risk. We used the Grading of Recommended Assessment Development and Evaluation (GRADE; Grade Pro version 3.6 .1$)^{15}$ to assess the quality of the evidence, which was categorized as high, moderate, low, and very low. The GRADE grading reduced the limitations of each study from high quality if any of the following limitations were present: 1) design limitations; 2) inconsistent results; 3) evidence of indirectness; 4) imprecision 5) reporting bias.

\section{Data Synthesis}

Meta-analysis was performed by the Review Manager (version 5.3). I-square $\left(\mathrm{I}^{2}\right)$ statistics and Cochran $\mathrm{Q}$ test assessed heterogeneity. ${ }^{16,17} \mathrm{I}^{2}<50 \%$ statistics or the P-value $>0.01$ was defined as low heterogeneity. When possible, we used a random-effects model for meta-analysis. For dichotomous variables, a risk ratio (RR) with a 95\% Confidence Intervals (CIs) was used. Other binary data would be converted into an RR value. Continuous variables were analyzed by the Hedges' g method and expressed as standardized mean difference (SMD) or mean difference (MD) with 95\% CIs. We combined studies that had the same form of acupuncture intervention and the same controls. Due to the small number of included studies and limitations in study quality, we did not perform subgroup analysis and sensitivity analysis. The funnel plot did not apply to this study because of the small number of included literatures. ${ }^{18}$ For RCTs with multiple treatment arms, data of comparisons that met inclusion criteria were extracted as recommended by The
Cochrane Handbook for Systematic Review of Interventions. ${ }^{14}$ For studies whose outcomes could not be combined, we performed a description for individual studies.

\section{Results}

\section{Results of Searches}

A total of 129 citations were retrieved. Forty duplicate studies were excluded. After screening titles and abstracts, a further 64 studies not consistent with the purpose and five with the wrong research type were excluded. Of the 20 identified trials, six studies did not meet the inclusion criteria (two ${ }^{19,20}$ with the wrong intervention or comparator, one ${ }^{21}$ without outcomes of interest, and three studies ${ }^{22-24}$ not available for full data) were excluded. Thus, 14 studies $^{8,25-37}$ were included in the study. The PRISMA flowchart of the screening process is shown in Figure 1.

Table 1 shows the characteristic of RCTs included in the review. Overall, 2503 women were enrolled in this review, with sample sizes ranging from 60 to 409 for each study. Of the 14 included studies, 10 studies $^{8,29-37}$ were conducted in mainland China. Five of the included studies $^{29-32,35}$ were published master's theses, and the remaining nine $8,25-28,33,34,36,37$ were journal articles. Five studies ${ }^{25-28,37}$ were published in English, and the other nine ${ }^{8,29-36}$ were published in Chinese. Five different acupuncture interventions were investigated: auricular point pressing, ${ }^{35}$ auricular electroacupuncture, ${ }^{28,34}$ electroacupuncture, ${ }^{8,25-27,29,31,33,36}$ TEAS, ${ }^{30,37}$ manual acupuncture. $^{32}$

The included studies investigated populations of women undergoing IVF with a slight difference. Six studies $^{25,26,27,31,33,34}$ recruited women undergoing IVF without other requirements. Thirteen studies $^{8,25-36}$ included women with a mean age of under 35 years for females, and only one study ${ }^{37}$ included women with a mean age of over 35 years. Two studies ${ }^{29,37}$ specifically recruited women with previous IVF experience, while two studies $^{30,35}$ required women undergoing the first-time IVF. Tian et $\mathrm{al}^{37}$ recruited women with five or fewer oocytes (diameter $>10 \mathrm{~mm}$ ) previously retrieved. See Table S1.

\section{Quality of Studies}

Figure 2 and Figure $\mathrm{S} 1$ demonstrated the risk of bias of the included studies. Only one study, ${ }^{30}$ which mentioned random methods, did not apply random sequence generation. Five studies ${ }^{25,26,28,31,37}$ applied allocation concealment. 


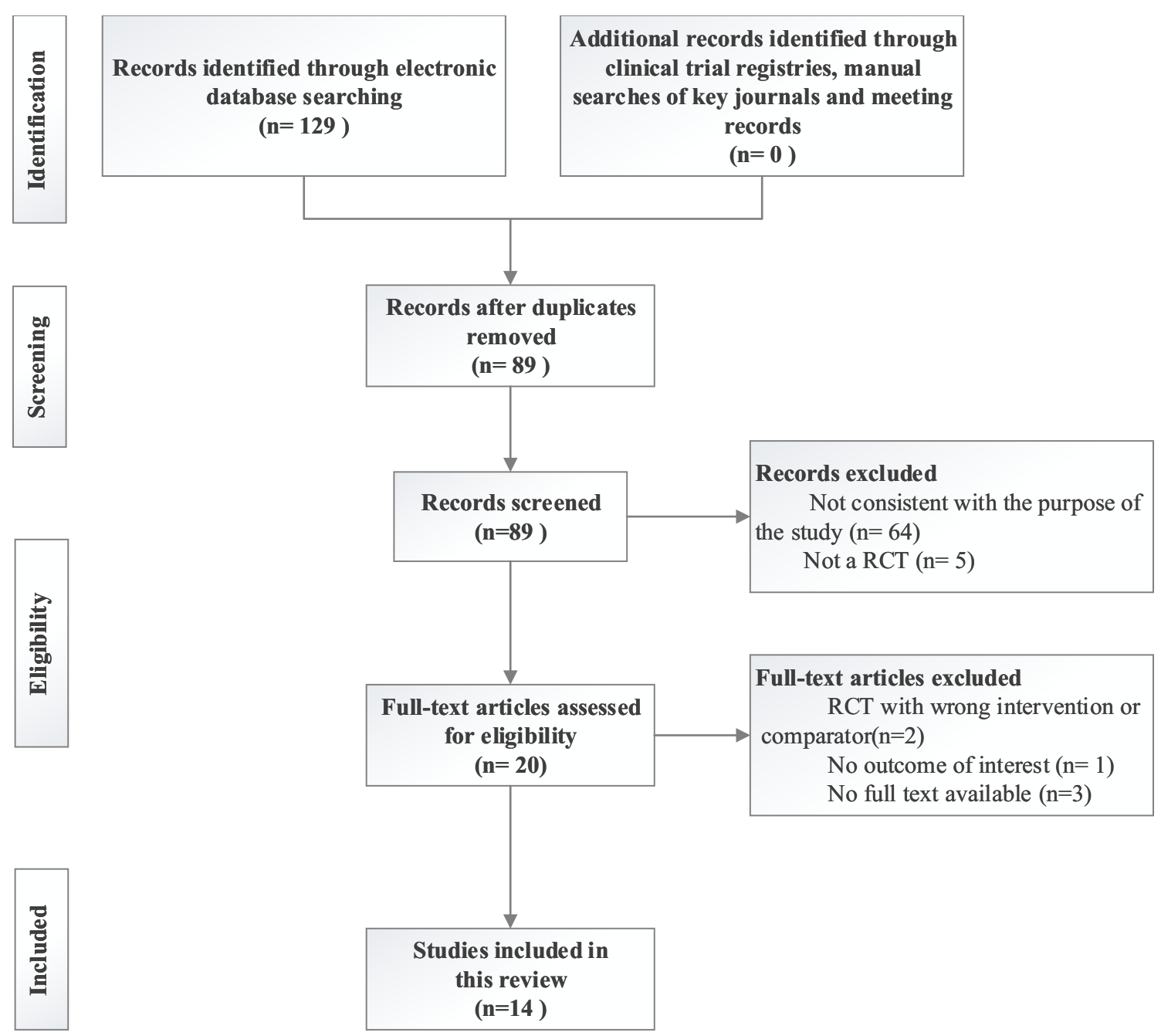

Figure I Flow diagram of the screening process.

Only two studies ${ }^{28,37}$ applied the blinding of participants. Details of missing data were not reported in all included studies except for one study ${ }^{32}$ that had selective reporting bias due to the suspected incomplete report. Five studies $^{29-32,34}$ remained other unclear bias. We assessed evidence to be generally of low or very low quality based on GRADE, owing to the high risk of bias and high heterogeneity. Self-rating scales as a primary indicator for evaluating pain were not high-quality evidence. The summary findings of various six interventions were conducted (see Table 2).

\section{Primary Outcomes}

Various criteria were used to evaluate analgesic effectiveness: pain scores and rating of WHO were used in three studies; ${ }^{8,29,33}$ SF-MPQ were used in three studies; ${ }^{30,32,35}$ eight studies ${ }^{25-29,31,34,35}$ also used VAS to evaluate pain intensity; two studies $^{34,36}$ conducted effective rate of analgesia (see Table 1). Eight studies $^{25-28,30,32,35,37}$ recorded pain scores at multiple time points (see Table $\underline{\mathrm{S} 2}$ ). We evaluated intraoperative and postoperative pain separately. The varied comparisons were as follows:

1. Electroacupuncture with $\mathrm{PCB}$ versus $\mathrm{CSA}$ with PCB;

2. Acupuncture stimulation (electroacupuncture) with CSA versus CSA;

3. Acupuncture stimulation versus CSA;

4. Acupuncture stimulation versus sham acupuncture stimulation;

5. Acupuncture stimulation with NASIDs versus sham acupuncture stimulation with NASIDs;

6. Acupuncture stimulation with NASIDs versus NASIDs. 
Table I Characteristic of RCTs Included in the Review

\begin{tabular}{|c|c|c|c|c|c|c|}
\hline Study & Country & $\begin{array}{l}\text { Multi/ } \\
\text { Single } \\
\text { Center(s) }\end{array}$ & $\begin{array}{l}\text { Sample Size, } \\
\text { Randomized / } \\
\text { Analyzed }\end{array}$ & Pain Measurement & Intervention/Contrrol & Time of Acupuncture Intervention \\
\hline $\begin{array}{l}\text { Stener-Victorin, } \\
\text { et al (1999) }\end{array}$ & Sweden & $\begin{array}{l}\text { Multi- } \\
\text { center }\end{array}$ & $150 / 149$ & VAS $(0-100)$ & $\begin{array}{l}\mathrm{EA}+\mathrm{PCB} \text { (lignocaine) } \\
\text { Alfentanil+Atropine } \\
+\mathrm{PCB} \text { (lignocaine) }\end{array}$ & $\begin{array}{l}\text { EA: } 30 \mathrm{~min} \text { before OPU till the end of the } \\
\text { procedure }\end{array}$ \\
\hline $\begin{array}{l}\text { Humaidan, et al } \\
(2004)\end{array}$ & Denmark & $\begin{array}{l}\text { Single- } \\
\text { center }\end{array}$ & $200 / 200$ & VAS $(0-100)$ & $\begin{array}{l}\text { EA+PCB (lignocaine)+ } \\
\text { Alfentanil } \\
\text { Alfentanil } \\
+ \text { +Benzodiazepine } \\
+ \text { PCB(lignocaine) }\end{array}$ & $\begin{array}{l}\text { EA: After the injection of propofol till the } \\
\text { end of the procedure }\end{array}$ \\
\hline $\begin{array}{l}\text { Gejervall, et al } \\
\text { (2005) }\end{array}$ & Sweden & $\begin{array}{l}\text { Multi- } \\
\text { center }\end{array}$ & $160 / 158$ & VAS $(0-100)$ & $\begin{array}{l}\text { EA+PCB(lignocaine) } \\
\text { Alfentanil+ Oral } \\
\text { flunitrazepam+Rectal } \\
\text { paracetamol } \\
+ \text { PCB(lignocaine) }\end{array}$ & $\begin{array}{l}\text { EA: } 30-45 \text { min before OPU till the end of } \\
\text { the procedure }\end{array}$ \\
\hline $\begin{array}{l}\text { Sator- } \\
\text { Katzenschlager, } \\
\text { et al (2006) }\end{array}$ & Austria & $\begin{array}{l}\text { Single- } \\
\text { center }\end{array}$ & $94 / 94$ & VAS $(0-10)$ & $\begin{array}{l}\text { Auricular EA+Metamizol } \\
\text { +Remifentanil } \\
\text { Auricular acupuncture } \\
\text { +Metamizol+ } \\
\text { Remifentanil } \\
\text { Metamizol+ Remifentanil }\end{array}$ & $\begin{array}{l}\text { Auricular EA or auricular acupuncture: } \\
30 \mathrm{~min} \text { before the procedure and last until } \\
\mathrm{I} \mathrm{h} \text { after the procedure }\end{array}$ \\
\hline $\begin{array}{l}\text { Meng, et al } \\
(2008)\end{array}$ & China & $\begin{array}{l}\text { Single- } \\
\text { center }\end{array}$ & $316 / 316$ & $\begin{array}{l}\text { Pain score of WHO (0- } \\
\text { 12); Pain rating of } \\
\text { WHO }\end{array}$ & $\begin{array}{l}\text { EA+ Dolantin } \\
\text { Dolantin }\end{array}$ & $\begin{array}{l}\text { EA: } 30 \text {-minute EA I day before OPU; EA } \\
\text { 30min before OPU till the end of the } \\
\text { procedure }\end{array}$ \\
\hline Xu, et al (2008) & China & $\begin{array}{l}\text { Single- } \\
\text { center }\end{array}$ & $120 / 111$ & $\begin{array}{l}\text { VAS }(0-100) \text {; Pain score } \\
\text { of WHO (0-12); Pain } \\
\text { rating of WHO }\end{array}$ & $\begin{array}{l}\text { EA+Dolantin } \\
\text { Dolantin }\end{array}$ & $\begin{array}{l}\text { EA: } 30 \text {-minute EA I day before OPU; } \\
30 \text { min before OPU till the end of the } \\
\text { procedure }\end{array}$ \\
\hline $\begin{array}{l}\text { Kong, et al } \\
(2009)\end{array}$ & China & $\begin{array}{l}\text { Single- } \\
\text { center }\end{array}$ & $60 / 60$ & $\begin{array}{c}\text { VAS }(0-10) ; \text { PRI }(0-45) \\
\text { PPI }(0-5)\end{array}$ & $\begin{array}{l}\text { TEAS+Dolantin } \\
\text { Dolantin }\end{array}$ & $\begin{array}{l}\text { TEAS: } 30 \mathrm{~min} \text { before OPU till the end of } \\
\text { the procedure }\end{array}$ \\
\hline Li, et al (20II) & China & $\begin{array}{l}\text { Single- } \\
\text { center }\end{array}$ & $409 / 409$ & VAS $(0-100)$ & $\begin{array}{l}\text { EA+Dolantin } \\
\text { Dolantin }\end{array}$ & $\begin{array}{l}\text { EA: } 30 \mathrm{~min} \text { before OPU till the end of the } \\
\text { procedure }\end{array}$ \\
\hline $\begin{array}{l}\text { Wang, et al } \\
(2011)\end{array}$ & China & $\begin{array}{l}\text { Single- } \\
\text { center }\end{array}$ & $90 / 90$ & $\begin{array}{l}\text { VAS }(0-10) ; \text { PRI }(0-45) ; \\
\text { PPI }(0-5)\end{array}$ & $\begin{array}{l}\text { MA+Indometacin } \\
\text { suppository } \\
\text { Sham MA+Indometacin } \\
\text { suppository } \\
\text { Indometacin suppository }\end{array}$ & $\begin{array}{l}\text { MA: } 15 \mathrm{~min} \text { before OPU till the end of the } \\
\text { procedure }\end{array}$ \\
\hline $\begin{array}{l}\text { Chen, et al } \\
(2012)\end{array}$ & China & $\begin{array}{l}\text { Single- } \\
\text { center }\end{array}$ & $134 / 134$ & $\begin{array}{l}\text { Pain score of WHO (0- } \\
\text { 12); Pain rating of } \\
\text { WHO }\end{array}$ & $\begin{array}{l}\text { EA+Dolantin } \\
\text { Dolantin }\end{array}$ & $\begin{array}{l}\text { EA: } 30 \mathrm{~min} \text { before OPU till the end of the } \\
\text { procedure }\end{array}$ \\
\hline $\begin{array}{l}\text { Chen, et al } \\
(2015)\end{array}$ & China & $\begin{array}{l}\text { Single- } \\
\text { center }\end{array}$ & $106 / 106$ & $\begin{array}{l}\text { VAS }(0-10) \text {; Effective } \\
\text { rate of analgesia }\end{array}$ & $\begin{array}{l}\text { Auricular EA (Point group } \\
\text { Auricular EA (Point group } \\
\text { Pethidine }\end{array}$ & $\begin{array}{l}\text { Auricular EA: } 10 \mathrm{~min} \text { before OPU till the } \\
\text { end of the procedure }\end{array}$ \\
\hline Fan, et al (2016) & China & $\begin{array}{l}\text { Single- } \\
\text { center }\end{array}$ & $90 / 90$ & $\begin{array}{l}\text { VAS }(0-10) ; \text { PRI }(0-45) \\
\text { PPI }(0-5)\end{array}$ & $\begin{array}{l}\text { Auricular point pressing } \\
\text { +Indometacin } \\
\text { suppository } \\
\text { Sham auricular point } \\
\text { pressing+Indometacin } \\
\text { suppository } \\
\text { Indometacin suppository }\end{array}$ & $\begin{array}{l}\text { Auricular point pressing: } 20 \mathrm{~min} \text { before } \\
\text { OPU, press the each auricular point for } 30 \\
\text { seconds with even force }\end{array}$ \\
\hline
\end{tabular}


Table I (Continued).

\begin{tabular}{|l|c|c|c|c|l|l|}
\hline Study & Country & $\begin{array}{c}\text { Multi/ } \\
\text { Single } \\
\text { Center(s) }\end{array}$ & $\begin{array}{c}\text { Sample Size, } \\
\text { Randomized / } \\
\text { Analyzed }\end{array}$ & Pain Measurement & Intervention/Contrrol & Time of Acupuncture Intervention \\
\hline $\begin{array}{l}\text { Yuan, et al } \\
(2017)\end{array}$ & China & $\begin{array}{c}\text { Single- } \\
\text { center }\end{array}$ & $182 / 182$ & $\begin{array}{c}\text { Effective rate of } \\
\text { analgesia }\end{array}$ & $\begin{array}{l}\text { EA+propofol } \\
\text { propofol }\end{array}$ & $\begin{array}{l}\text { EA: After the injection of propofol till the } \\
\text { end of the procedure }\end{array}$ \\
\hline $\begin{array}{l}\text { Tian, et al } \\
(2020)\end{array}$ & China & $\begin{array}{l}\text { Multi- } \\
\text { center }\end{array}$ & $392 / 390$ & VAS (0-100); & $\begin{array}{l}\text { TEAS } \\
\text { Mock TEAS }\end{array}$ & $\begin{array}{l}\text { TEAS: 30min before OPU till the end of } \\
\text { the procedure }\end{array}$ \\
\hline
\end{tabular}

Abbreviations: VAS, visual analog scale; EA, electroacupuncture; PCB, paracervical block; OPU, oocyte pick-up; min, minute; MA, manual acupuncture; TEAS, transcutaneous electrical acupoint stimulation; WHO, World Health Organization; PRI, pain rating index; PPI, present pain intensity.

\section{Simple Self-Rating Scale}

Scores were pooled according to different scales (WHO pain rating scale or VAS). Meta-analysis showed that the analgesic intervention of PCB with CSA had a significant reduction in pain intensity than electroacupuncture with $\mathrm{PCB}$ during $\mathrm{OPU}$ ( $\mathrm{SMD}=0.45,95 \% \mathrm{CI}$ : 0.14 to 0.76 , Figure $3 \mathrm{~A}$ ). Three comparisons showed less intraoperative pain during OPU with acupuncture stimulation with CSA compared to CSA alone, with VAS scores of -1.03 ( $\mathrm{SMD}=-1.03,95 \% \mathrm{CI}$ : -1.71 to -0.36 , Figure 3B). Electroacupuncture with CSA showed better analgesia than CSA alone evaluated by WHO pain scores of -1.21 ( $\mathrm{MD}=-1.21,95 \% \mathrm{CI}:-2.18$ to -0.25 , Figure $3 \mathrm{C}$ ).

It was significantly lower postoperative pain of the acupuncture stimulation with CSA than CSA (SMD= $-1.11,95 \%$ CI: -1.51 to -0.71 , Figure $4 \mathrm{~A})$. There was a significantly higher analgesic effect in the acupuncture stimulation with NSAIDs than sham acupuncture stimulation with NSAIDs (MD $=-1.76,95 \%$ CI: -2.08 to -1.44 , Figure $4 \mathrm{~B})$. Investigators ${ }^{37}$ found that TEAS was associated with less pain when compared with mock TEAS $(\mathrm{MD}=-5.80,95 \% \mathrm{CI}:-6.10$ to -5.55$)$. Better analgesia effects were found in acupuncture stimulation with NSAIDs than NSAIDs (MD $=-1.96,95 \% \mathrm{CI}:-2.32$ to -1.60 , Figure $4 \mathrm{C})$. Chen et al study ${ }^{34}$ recorded that auricular electroacupuncture of two acupoint schemes was lower of postoperative VAS scores compared with CSA $(\mathrm{P}<0.05)$. An absolutely opposite result was that electroacupuncture with PCB showed the worse analgesic effect of PCB with CSA (SMD $=0.30$; 95\% CI: 0.12 to 0.47 , Figure 4D).

\section{Present Pain Intensity and Pain Rating Index}

There were significantly lower PPI scores of acupuncture stimulation with NSAIDs with high heterogeneity than sham acupuncture stimulation with NSAIDs under random models of whether directly after OPU $(\mathrm{MD}=-0.79,95 \%$ CI: -0.99 to -0.59 , Figure $5 \mathrm{~A}$ ) or one hour later $(\mathrm{MD}=$ $-0.49,95 \%$ CI: -0.65 to -0.34 , Figure $5 \mathrm{~B}$ ). Acupuncture stimulation with NSAIDs also demonstrated lower PPI than NSAIDs whether directly $(\mathrm{MD}=-0.94,95 \% \mathrm{CI}$ : -1.18 to -0.71 , Figure $5 \mathrm{C})$ or one hour after OPU $(\mathrm{MD}=$ $-0.32,95 \%$ CI: -0.47 to -0.17 , Figure 5D). One study ${ }^{30}$ showed that participants undergoing TEAS with CSA had lower PPI scores than CSA alone, whether directly (MD= $-1.43,95 \%$ CI: -2.00 to -0.86 ) or one hour after OPU $(\mathrm{MD}=-0.94,95 \% \mathrm{CI}:-1.24$ to -0.64$)$.

Significantly lower PRI scores were observed in groups treated with acupuncture with NSAIDs versus sham acupuncture with NSAIDs under random models of whether directly after OPU ( $\mathrm{MD}=-4.31,95 \% \mathrm{CI}:-4.80$ to -3.82 , Figure $6 \mathrm{~A}$ ) or one hour later ( $\mathrm{MD}=-1.05,95 \% \mathrm{CI}:-1.27$ to -0.82 , Figure $6 \mathrm{~B})$. NSAIDs was associated with a higher PRI than acupuncture with NSAIDs directly ( $\mathrm{MD}=-4.15,95 \%$ CI: -4.74 to -3.56 , Figure $6 \mathrm{C}$ ) or one hour after OPU (MD= $-1.17,95 \%$ CI: -1.40 to -0.94 , Figure $6 \mathrm{D}$ ). CSA was associated with higher PRI scores than TEAS combined with CSA calculated in Kong's study ${ }^{30}$ whether directly (MD= $-1.03,95 \%$ CI: -1.70 to -0.36 ) or one hour after OPU (MD= $-0.56,95 \%$ CI: -0.93 to -0.19 ).

\section{Effective Rates of Pain Intensity}

In two studies, ${ }^{34,36}$ effective analgesia was defined as patients having no pain or mild pain during OPU. According to WHO rating, one study ${ }^{29}$ defined grade I, II, III as the corresponding intervention; otherwise, the analgesic efficacy is invalid (grade IV). Of two studies, ${ }^{8,33}$ the analgesic effect graded excellent or good were defined as the corresponding intervention otherwise invalid (grade poor). There was no significant difference in the effective rate in reducing oocyte retrieval pain of acupuncture with CSA than CSA alone (RR=1.02, 95\% CI: 1.00 to 1.04 , 


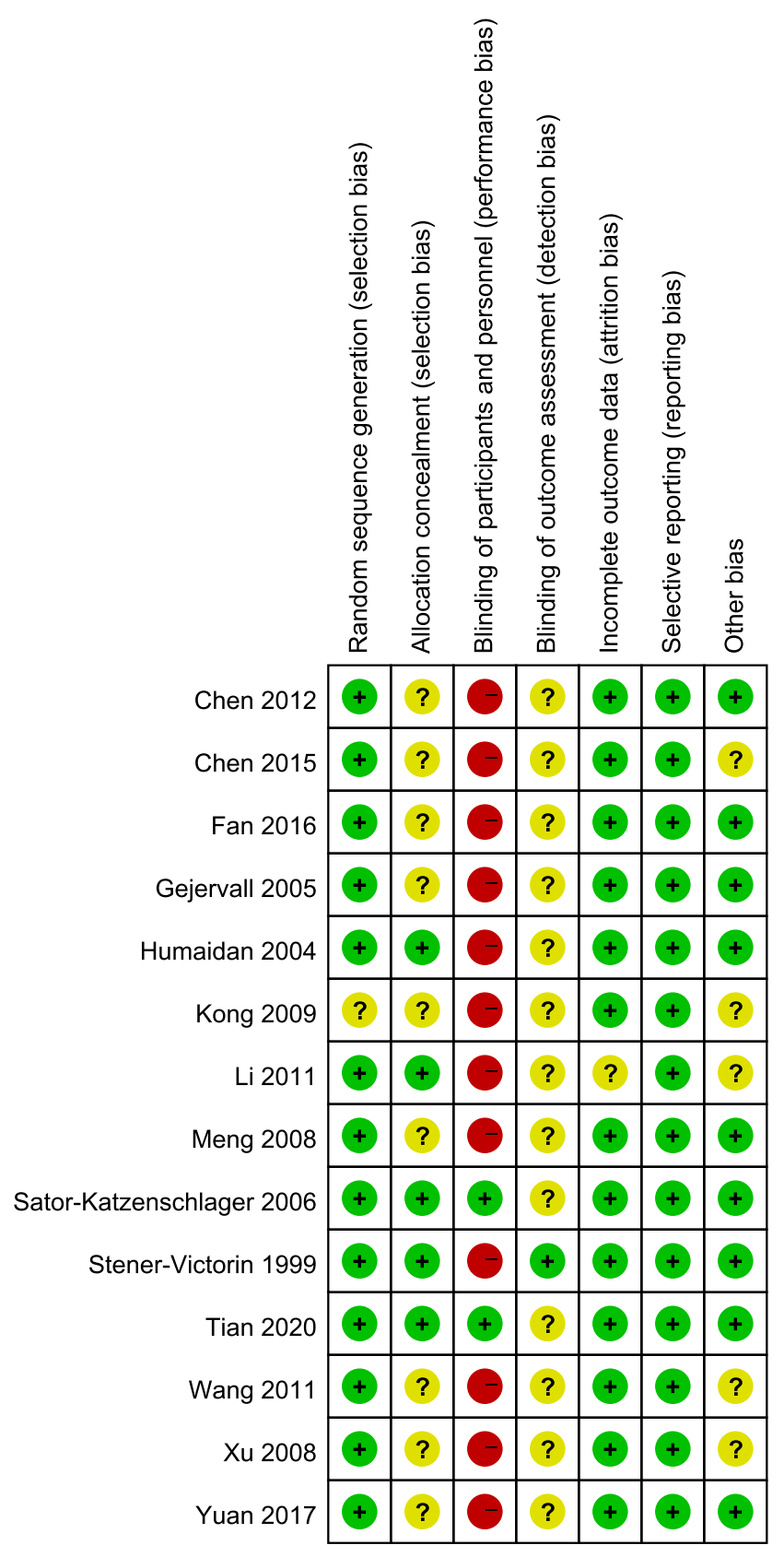

Figure 2 Review authors' judgments about each risk of bias item for each included study.

Figure S2). This finding was supported by another study, ${ }^{35}$ CSA was only associated with more pain during oocyte retrieval than auricular electroacupuncture of two different acupoint selection schemes (auricular electroacupuncture group: 35/36, 97.2\%; versus CSA group: 33/34, 97.05\%).

\section{Secondary Outcomes} The Number of Oocytes Retrieved

A total of seven studies ${ }^{27,28,30-32,34,35}$ reported the number of oocytes retrieved that there was no significant difference observed in any comparisons. Meta-analysis showed no significant difference of the number of oocytes retrieved in acupuncture stimulation with NSAIDs group with either sham acupuncture with NSAIDs group (MD= $-1.75,95 \%$ CI: -3.53 to -0.04 , Figure S3a) or NSAIDs $(\mathrm{MD}=-0.83,95 \% \mathrm{CI}:-2.66$ to 1.00 , Figure $\mathrm{S} 3 \mathrm{~b})$. Measurement of acupuncture with CSA ( $\mathrm{MD}=0.15,95 \%$ CI: -1.28 to 1.58 , Figure S3c) did not show advantages over CSA in the number of oocytes retrieved. Electroacupuncture with PCB showed no significant difference in the number of oocytes retrieved with CSA and PCB $(\mathrm{P}=0.06)$ in Gejervall et al study. ${ }^{27}$

\section{Other Pregnancy Outcomes}

We have documented and described pregnancy outcomes as follows: clinical pregnancy rates, quality embryo rates, fertilization rates, and abortion rates due to high heterogeneity. Five studies ${ }^{30-32,35,36}$ reported the clinical pregnancy rate after the intervention, but there was no difference between the intervention and control groups $(\mathrm{P}>0.05)$. Three studies $^{30,32,35}$ reported the high-quality embryo rate after the intervention, but there was no difference between the intervention group and control groups $(\mathrm{P}>0.05)$. Four studies ${ }^{30,32,35,36}$ reported the fertilization rate after the intervention. Yuan's study ${ }^{36}$ reported the fertilization rate per woman, and there was no significant difference between the acupuncture group and the control group ( $\mathrm{P}>0.05)$. There was no significant difference in the total fertilization rate of the other three studies $^{30,32,35}$ between the acupuncture group and the control group $(\mathrm{P}>0.05)$. Two studies ${ }^{31,36}$ reported the abortion rate after the intervention, but there was no difference between the intervention and control groups $(\mathrm{P}>0.05)$ (see Tables S3S6).

\section{Operation Related Indexes}

Adverse Reactions

Six studies ${ }^{8,28,29,33,35,36}$ discussed the types of adverse reactions after surgery and the corresponding number of patients. The adverse reactions of OPU mainly included nausea, vomiting, and dizziness (see Table S7).

\section{Emotion Changes}

Four studies ${ }^{25-27,29}$ evaluated the emotional changes of participants at different time points. The results are uncertain because of different measurement standards. For preoperative emotions, one study ${ }^{25}$ demonstrated women in the acupuncture group were more stressed $(\mathrm{P}<0.05)$, a different result was found in another two studies $^{26,27}$ 
Table 2 Quality of Evidence Based on GRADE

\begin{tabular}{|c|c|c|c|c|c|}
\hline \multirow[t]{3}{*}{ Outcome Indicators (No. of Comparisons) } & \multicolumn{5}{|c|}{ Result Summary } \\
\hline & \multicolumn{2}{|c|}{ No. of Participants } & \multicolumn{2}{|c|}{$\begin{array}{c}\text { Effect Measurement } \\
(95 \% \mathrm{Cl})\end{array}$} & \multirow[t]{2}{*}{$\begin{array}{l}\text { Quality of } \\
\text { Evidence }\end{array}$} \\
\hline & $\begin{array}{l}\text { Intervention } \\
\text { Group }\end{array}$ & $\begin{array}{l}\text { Control } \\
\text { Group }\end{array}$ & $\begin{array}{l}\text { Relative } \\
\text { Effect }\end{array}$ & Absolute Effect & \\
\hline \multicolumn{6}{|c|}{ Electroacupuncture with PCB versus PCB with CSA } \\
\hline $\begin{array}{l}\text { Intraoperative pain measured by VAS ( } 3 \text { comparisons } \\
\text { of } 3 \text { RCTs) }\end{array}$ & 253 & 254 & - & $\begin{array}{c}\text { SMD } 0.74 \\
(0.42 \text { to } 1.06)\end{array}$ & $\begin{array}{l}\oplus \oplus \bigcirc \bigcirc \\
\text { Low }^{\text {a, b }}\end{array}$ \\
\hline $\begin{array}{l}\text { Postoperative pain measured by VAS } \\
\text { ( } 3 \text { comparisons of } 3 \text { RCTs) }\end{array}$ & 253 & 254 & - & $\begin{array}{c}\text { SMD } 0.30 \\
(0.12 \text { to } 0.47)\end{array}$ & $\begin{array}{l}\oplus \oplus \bigcirc \bigcirc \\
\text { Low }^{\text {a, b }}\end{array}$ \\
\hline $\begin{array}{l}\text { Number of oocytes retrieved } \\
\text { (I comparison of I RCT) }\end{array}$ & 78 & 80 & - & $\begin{array}{c}\text { MD } 2.00 \\
(-0.04 \text { to } 4.04)\end{array}$ & $\begin{array}{l}\bigoplus \oplus \bigcirc \bigcirc \\
\text { Low }^{\text {a, c }}\end{array}$ \\
\hline $\begin{array}{l}\text { Adverse reactions } \\
\text { (I comparison of I RCT) }\end{array}$ & - & - & $\begin{array}{c}\text { Not } \\
\text { estimate }\end{array}$ & - & $\begin{array}{l}\bigoplus \oplus \bigcirc \bigcirc \\
\text { Low }^{\text {a, c }}\end{array}$ \\
\hline \multicolumn{6}{|l|}{ Acupuncture stimulation with CSA versus CSA } \\
\hline $\begin{array}{l}\text { Intraoperative pain measured by VAS } \\
\text { ( } 3 \text { comparisons of } 2 \text { RCTs) }\end{array}$ & 212 & 210 & - & $\begin{array}{c}\text { SMD }-1.03 \\
(-1.7 \mid \text { to }-0.36)\end{array}$ & $\begin{array}{l}\oplus \oplus \bigcirc \bigcirc \\
\text { Low }^{\text {a, b }}\end{array}$ \\
\hline $\begin{array}{l}\text { Intraoperative pain measured by WHO pain scores } \\
\text { ( } 3 \text { comparisons of } 3 \text { RCTs) }\end{array}$ & 272 & 289 & - & $\begin{array}{c}M D-1.21 \\
(-2.18,-0.25)\end{array}$ & $\begin{array}{l}\oplus \oplus \bigcirc \bigcirc \\
\text { Low }^{\text {a, b }}\end{array}$ \\
\hline $\begin{array}{l}\text { Postoperative pain measured by simple numeral self- } \\
\text { rating scale ( } 2 \text { comparisons of } 2 \text { RCTs) }\end{array}$ & 89 & 82 & - & $\begin{array}{c}\text { SMD }-I . I I \\
(-I .5 I \text { to }-0.7 I)\end{array}$ & $\begin{array}{l}\oplus \oplus \bigcirc \bigcirc \\
\text { Low }^{\text {a, e }}\end{array}$ \\
\hline $\begin{array}{l}\text { Present pain intensity one hour after OPU } \\
\text { (I comparison of I RCT) }\end{array}$ & 30 & 30 & - & $\begin{array}{c}M D-1.43 \\
(-2.00 \text { to }-0.86)\end{array}$ & $\begin{array}{l}\bigoplus \oplus \bigcirc \bigcirc \\
\text { Low }^{\text {a, e }}\end{array}$ \\
\hline $\begin{array}{l}\text { Present pain intensity directly after OPU } \\
\text { (I comparison of I RCT) }\end{array}$ & 30 & 30 & - & $\begin{array}{c}M D-0.94 \\
(-1.24,-0.64)\end{array}$ & $\begin{array}{l}\bigoplus \oplus \bigcirc \bigcirc \\
\text { Low }^{\text {a, e }}\end{array}$ \\
\hline $\begin{array}{l}\text { Pain rating index directly after OPU } \\
\text { (I comparison of I RCT) }\end{array}$ & 30 & 30 & - & $\begin{array}{c}M D-1.03 \\
(-1.70,-0.36)\end{array}$ & $\begin{array}{l}\oplus \oplus \bigcirc \bigcirc \\
\text { Low }^{\text {a, e }}\end{array}$ \\
\hline $\begin{array}{l}\text { Pain rating index one hour after OPU } \\
\text { (I comparison of I RCT) }\end{array}$ & 30 & 30 & - & $\begin{array}{c}M D-0.78 \\
(-0.89 \text { to }-0.67)\end{array}$ & $\begin{array}{l}\oplus \oplus \bigcirc \bigcirc \\
\text { Low }^{\text {a, e }}\end{array}$ \\
\hline $\begin{array}{l}\text { Effective rates of pain intensity } \\
\text { ( } 4 \text { comparisons of } 4 \text { RCTs) }\end{array}$ & 359 & 366 & $\begin{array}{l}\text { OR } 2.20 \\
(0.82 \text { to } \\
5.87)\end{array}$ & - & $\begin{array}{l}\oplus \bigcirc \bigcirc \bigcirc \\
\text { Very Low }{ }^{\text {a, b, d }}\end{array}$ \\
\hline $\begin{array}{l}\text { Number of oocytes retrieved } \\
\text { ( } 4 \text { comparisons of } 3 \text { RCTs) }\end{array}$ & 242 & 240 & - & $\begin{array}{c}\text { SMD } 0.15 \\
(-1.28 \text { to } 1.58)\end{array}$ & $\begin{array}{l}\oplus \oplus \bigcirc \bigcirc \\
\text { Low }^{\text {a, c }}\end{array}$ \\
\hline $\begin{array}{l}\text { Clinical pregnancy rate } \\
\text { ( } 3 \text { comparisons of } 3 \text { RCTs) }\end{array}$ & - & - & - & Not estimate & $\begin{array}{l}\oplus \oplus \bigcirc \bigcirc \\
\text { Low }^{\text {a, c }}\end{array}$ \\
\hline $\begin{array}{l}\text { High-quality embryo rate } \\
\text { (I comparison of I RCT) }\end{array}$ & - & - & $\begin{array}{c}\text { Not } \\
\text { estimate }\end{array}$ & - & $\begin{array}{c}\oplus \bigcirc \bigcirc \bigcirc \\
\text { Very Low }{ }^{\text {a, c, e }}\end{array}$ \\
\hline $\begin{array}{l}\text { Fertilization rate } \\
\text { ( } 2 \text { comparisons of } 2 \text { RCTs) }\end{array}$ & - & - & $\begin{array}{c}\text { NOT } \\
\text { estimate }\end{array}$ & - & $\begin{array}{c}\oplus \bigcirc \bigcirc \bigcirc \\
\text { Very Low }{ }^{\text {a, c, e }}\end{array}$ \\
\hline
\end{tabular}

(Continued) 
Table 2 (Continued).

\begin{tabular}{|c|c|c|c|c|c|}
\hline \multirow[t]{3}{*}{ Outcome Indicators (No. of Comparisons) } & \multicolumn{5}{|c|}{ Result Summary } \\
\hline & \multicolumn{2}{|c|}{ No. of Participants } & \multicolumn{2}{|c|}{$\begin{array}{l}\text { Effect Measurement } \\
\qquad(95 \% \mathrm{Cl})\end{array}$} & \multirow[t]{2}{*}{$\begin{array}{l}\text { Quality of } \\
\text { Evidence }\end{array}$} \\
\hline & $\begin{array}{l}\text { Intervention } \\
\text { Group }\end{array}$ & $\begin{array}{l}\text { Control } \\
\text { Group }\end{array}$ & $\begin{array}{l}\text { Relative } \\
\text { Effect }\end{array}$ & Absolute Effect & \\
\hline $\begin{array}{l}\text { Abortion rate } \\
\text { ( } 2 \text { comparisons of } 2 \mathrm{RCTs})\end{array}$ & - & - & $\begin{array}{l}\text { Not } \\
\text { estimate }\end{array}$ & - & $\begin{array}{l}\oplus \bigcirc \bigcirc \bigcirc \\
\text { Very Low }{ }^{\text {a, c, e }}\end{array}$ \\
\hline $\begin{array}{l}\text { Content of } \beta \text {-endorphin in serum } \\
\text { (I comparison of I RCT) }\end{array}$ & - & - & - & Not estimate & $\begin{array}{l}\oplus \bigcirc \bigcirc \bigcirc \\
\text { Very Low }{ }^{\text {a, c, e }}\end{array}$ \\
\hline $\begin{array}{l}\text { Adverse reactions } \\
\text { ( } 2 \text { comparisons of } 2 \text { RCTs) }\end{array}$ & - & - & $\begin{array}{c}\text { Not } \\
\text { estimate }\end{array}$ & - & $\begin{array}{l}\oplus \oplus \bigcirc \bigcirc \\
\text { Low }^{\text {a, c }}\end{array}$ \\
\hline $\begin{array}{l}\text { Emotion evaluations } \\
\text { (I comparison of I RCT) }\end{array}$ & - & - & - & Not estimate & $\begin{array}{l}\oplus \bigcirc \bigcirc \bigcirc \\
\text { Very Low } \\
\text { a, c, e }\end{array}$ \\
\hline \multicolumn{6}{|c|}{ Acupuncture stimulation versus sham acupuncture stimulation } \\
\hline $\begin{array}{l}\text { Postoperative pain measured by simple numeral self- } \\
\text { rating scale (I comparison of I RCT) }\end{array}$ & 196 & 194 & - & $\begin{array}{c}\text { MD } 3.82 \\
(3.49 \text { to } 4.16)\end{array}$ & $\begin{array}{l}\oplus \oplus \oplus \bigcirc \\
\text { Moderate }^{\text {a }}\end{array}$ \\
\hline $\begin{array}{l}\text { Content of } \beta \text {-endorphin in serum } \\
\text { (I comparison of I RCT) }\end{array}$ & - & - & - & Not estimate & $\begin{array}{l}\bigoplus \oplus \bigcirc \bigcirc \\
\text { Low }^{\text {a, c }}\end{array}$ \\
\hline \multicolumn{6}{|c|}{ Acupuncture stimulation with NASIDs versus sham acupuncture stimulation with NASIDs } \\
\hline $\begin{array}{l}\text { Postoperative pain measured by simple numeral self- } \\
\text { rating scale ( } 2 \text { comparisons of } 2 \text { RCTs) }\end{array}$ & 60 & 60 & - & $\begin{array}{c}M D-1.76 \\
(-2.08 \text { to }-1.44)\end{array}$ & $\begin{array}{l}\oplus \oplus \bigcirc \bigcirc \\
\text { Low }^{\text {a, e }}\end{array}$ \\
\hline $\begin{array}{l}\text { Present pain intensity directly after OPU } \\
\text { ( } 2 \text { comparisons of } 2 \mathrm{RCTs} \text { ) }\end{array}$ & 60 & 60 & - & $\begin{array}{c}M D-0.79 \\
(-0.99 \text { to }-0.59)\end{array}$ & $\begin{array}{l}\oplus \oplus \bigcirc \bigcirc \\
\text { Low }^{\text {a, e }}\end{array}$ \\
\hline $\begin{array}{l}\text { Present pain intensity one hour after OPU } \\
\text { ( } 2 \text { comparisons of } 2 \text { RCTs) }\end{array}$ & 60 & 60 & - & $\begin{array}{c}M D-0.49 \\
(-0.65 \text { to }-0.34)\end{array}$ & $\begin{array}{l}\oplus \oplus \bigcirc \bigcirc \\
\text { Low }^{\text {a, e }}\end{array}$ \\
\hline $\begin{array}{l}\text { Pain rating index directly after OPU } \\
\text { ( } 2 \text { comparisons of } 2 \text { RCTs) }\end{array}$ & 60 & 60 & - & $\begin{array}{c}M D-4.31 \\
(-4.80 \text { to }-3.82)\end{array}$ & $\begin{array}{l}\oplus \oplus \bigcirc \bigcirc \\
\text { Low }^{\text {a, e }}\end{array}$ \\
\hline $\begin{array}{l}\text { Pain rating index one hour after OPU } \\
\text { ( } 2 \text { comparisons of } 2 \text { RCTs) }\end{array}$ & 60 & 60 & - & $\begin{array}{c}M D-1.05 \\
(-1.27 \text { to }-0.82)\end{array}$ & $\begin{array}{l}\oplus \oplus \bigcirc \bigcirc \\
\text { Low }^{\text {a, e }}\end{array}$ \\
\hline $\begin{array}{l}\text { Number of oocytes retrieved } \\
\text { ( } 2 \text { comparisons of } 2 \text { RCTs) }\end{array}$ & 60 & 60 & - & $\begin{array}{c}M D-1.75 \\
(-3.53 \text { to } 0.04)\end{array}$ & $\begin{array}{l}\oplus \bigcirc \bigcirc \bigcirc \\
\text { Very Low }{ }^{\text {a, c, e }}\end{array}$ \\
\hline $\begin{array}{l}\text { High-quality embryo rate } \\
\text { ( } 2 \text { comparisons of } 2 \text { RCTs) }\end{array}$ & - & - & $\begin{array}{l}\text { Not } \\
\text { estimate }\end{array}$ & - & $\begin{array}{l}\oplus \bigcirc \bigcirc \bigcirc \\
\text { Very Low }{ }^{\text {a, c, e }}\end{array}$ \\
\hline $\begin{array}{l}\text { Fertilization rate } \\
\text { ( } 2 \text { comparisons of } 2 \text { RCTs) }\end{array}$ & - & - & $\begin{array}{l}\text { Not } \\
\text { estimate }\end{array}$ & - & $\begin{array}{l}\oplus \bigcirc \bigcirc \bigcirc \\
\text { Very Low }{ }^{\text {a, c, e }}\end{array}$ \\
\hline $\begin{array}{l}\text { Content of } \beta \text {-endorphin in serum } \\
\text { (I comparison of I RCT) }\end{array}$ & - & - & - & Not estimate & $\begin{array}{l}\oplus \bigcirc \bigcirc \bigcirc \\
\text { Very Low }{ }^{\text {a, c, e }}\end{array}$ \\
\hline $\begin{array}{l}\text { Adverse reactions } \\
\text { ( } 2 \text { comparisons of } 2 \text { RCTs) }\end{array}$ & - & - & $\begin{array}{c}\text { Not } \\
\text { estimate }\end{array}$ & - & $\begin{array}{c}\oplus \bigcirc \bigcirc \bigcirc \\
\text { Very Low }^{\text {a, c, e }}\end{array}$ \\
\hline
\end{tabular}


Table 2 (Continued).

\begin{tabular}{|c|c|c|c|c|c|}
\hline \multirow[t]{3}{*}{ Outcome Indicators (No. of Comparisons) } & \multicolumn{5}{|c|}{ Result Summary } \\
\hline & \multicolumn{2}{|c|}{ No. of Participants } & \multicolumn{2}{|c|}{$\begin{array}{l}\text { Effect Measurement } \\
\qquad(95 \% \mathrm{CI})\end{array}$} & \multirow[t]{2}{*}{$\begin{array}{l}\text { Quality of } \\
\text { Evidence }\end{array}$} \\
\hline & $\begin{array}{l}\text { Intervention } \\
\text { Group }\end{array}$ & $\begin{array}{l}\text { Control } \\
\text { Group }\end{array}$ & $\begin{array}{l}\text { Relative } \\
\text { Effect }\end{array}$ & Absolute Effect & \\
\hline \multicolumn{6}{|c|}{ Acupuncture stimulation with NASIDs versus NASIDs } \\
\hline $\begin{array}{l}\text { Postoperative pain measured by simple numeral self- } \\
\text { rating scale } \\
(2 \text { comparisons of } 2 \text { RCTs) }\end{array}$ & 60 & 60 & - & $\begin{array}{c}M D-1.96 \\
(-2.32 \text { to } 1.69)\end{array}$ & $\begin{array}{l}\oplus \oplus \bigcirc \bigcirc \\
\text { Low }^{\text {a, e }}\end{array}$ \\
\hline $\begin{array}{l}\text { Present pain intensity directly after OPU } \\
\text { ( } 2 \text { comparisons of } 2 \text { RCTs) }\end{array}$ & 60 & 60 & - & $\begin{array}{c}M D-0.94 \\
(-I .18 \text { to }-0.7 I)\end{array}$ & $\begin{array}{l}\oplus \oplus \bigcirc \bigcirc \\
\text { Low }^{\text {a, e }}\end{array}$ \\
\hline $\begin{array}{l}\text { Present pain intensity one hour after OPU } \\
\text { ( } 2 \text { comparisons of } 2 \text { RCTs) }\end{array}$ & 60 & 60 & - & $\begin{array}{c}M D-0.32 \\
(-0.47 \text { to }-0.17)\end{array}$ & $\begin{array}{l}\oplus \oplus \bigcirc \bigcirc \\
\text { Low }^{\text {a, e }}\end{array}$ \\
\hline $\begin{array}{l}\text { Pain rating index directly after OPU } \\
\text { ( } 2 \text { comparisons of } 2 \mathrm{RCTs} \text { ) }\end{array}$ & 60 & 60 & - & $\begin{array}{c}M D-4.15 \\
(-4.74 \text { to }-3.56)\end{array}$ & $\begin{array}{l}\oplus \oplus \bigcirc \bigcirc \\
\text { Low }^{\text {a, e }}\end{array}$ \\
\hline $\begin{array}{l}\text { Pain rating index one hour after OPU } \\
\text { ( } 2 \text { comparisons of } 2 \text { RCTs) }\end{array}$ & 60 & 60 & - & $\begin{array}{c}M D-1.17 \\
(-1.40 \text { to }-0.94)\end{array}$ & $\begin{array}{l}\oplus \oplus \bigcirc \bigcirc \\
\text { Low }^{\text {a, e }}\end{array}$ \\
\hline $\begin{array}{l}\text { Number of oocytes retrieved } \\
\text { ( } 2 \text { comparisons of } 2 \text { RCTs) }\end{array}$ & 60 & 60 & - & $\begin{array}{c}M D-0.83 \\
(-2.66 \text { to } 1.00)\end{array}$ & $\begin{array}{l}\oplus \bigcirc \bigcirc \bigcirc \\
\text { Very Low }^{\text {a, c, e }}\end{array}$ \\
\hline $\begin{array}{l}\text { High-quality embryo rate } \\
(2 \text { comparisons of } 2 \text { RCTs) }\end{array}$ & - & - & $\begin{array}{c}\text { Not } \\
\text { estimate }\end{array}$ & - & $\begin{array}{l}\bigoplus \bigcirc \bigcirc \bigcirc \\
\text { Very Low }{ }^{\text {a, c, e }}\end{array}$ \\
\hline $\begin{array}{l}\text { Fertilization rate } \\
\text { ( } 2 \text { comparisons of } 2 \text { RCTs) }\end{array}$ & - & - & $\begin{array}{c}\text { Not } \\
\text { estimate }\end{array}$ & - & $\begin{array}{l}\bigoplus \bigcirc \bigcirc \bigcirc \\
\text { Very Low }{ }^{\text {a, c, e }}\end{array}$ \\
\hline $\begin{array}{l}\text { Content of } \beta \text {-endorphin in serum } \\
\text { (I comparison of I RCT) }\end{array}$ & - & - & - & Not estimate & $\begin{array}{l}\oplus \bigcirc \bigcirc \bigcirc \\
\text { Very Low }{ }^{\text {a, c, e }}\end{array}$ \\
\hline $\begin{array}{l}\text { Adverse reactions } \\
(2 \text { comparisons of } 2 \text { RCTs) }\end{array}$ & - & - & $\begin{array}{c}\text { Not } \\
\text { estimate }\end{array}$ & - & $\begin{array}{l}\oplus \bigcirc \bigcirc \bigcirc \\
\text { Very Low }{ }^{\text {a, c, e }}\end{array}$ \\
\hline \multicolumn{6}{|l|}{ Acupuncture stimulation versus CSA } \\
\hline $\begin{array}{l}\text { Postoperative pain measured by simple numeral self- } \\
\text { rating scale ( } 2 \text { comparisons of I RCT) }\end{array}$ & - & - & - & Not estimate & $\begin{array}{l}\bigoplus \oplus \bigcirc \bigcirc \\
\text { Low }^{\text {a, e }}\end{array}$ \\
\hline $\begin{array}{l}\text { Effective rates of pain intensity } \\
\text { ( } 2 \text { comparisons of I RCT) }\end{array}$ & - & - & $\begin{array}{l}\text { Not } \\
\text { estimate }\end{array}$ & - & $\begin{array}{l}\oplus \oplus \bigcirc \bigcirc \\
\text { Low }^{\text {a, e }}\end{array}$ \\
\hline $\begin{array}{l}\text { Number of oocytes retrieved } \\
\text { ( } 2 \text { comparisons of I RCT) }\end{array}$ & - & - & - & Not estimate & $\begin{array}{l}\oplus \oplus \bigcirc \bigcirc \\
\text { Low }^{\text {a, e }}\end{array}$ \\
\hline $\begin{array}{l}\text { Adverse reactions } \\
\text { ( } 2 \text { comparisons of I RCT) }\end{array}$ & - & - & $\begin{array}{l}\text { Not } \\
\text { estimate }\end{array}$ & - & $\begin{array}{l}\oplus \bigcirc \bigcirc \bigcirc \\
\text { Very Low }^{\text {a, c, e }}\end{array}$ \\
\hline
\end{tabular}

Notes: a Download one level for serious risk of bias: included studies did not conduct the blinding method, and unclear risk of bias in one or two domains. ${ }^{b}$ Downgraded one level for serious inconsistent: interventions of included studies inconsistent, or the outcome indicators exist statistical heterogeneous. ${ }^{\mathrm{D}} \mathrm{Downgraded}$ one level for serious indirectness: this outcome index cannot directly represent the analgesic effect of acupuncture. 'Downgraded one level for serious imprecision: some studies still

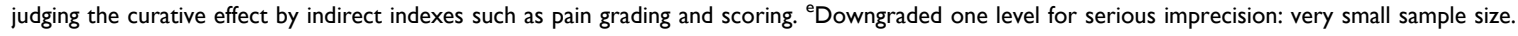

that there was no difference between their groups $(\mathrm{P}>0.05)$. Two studies showed that there was no difference in an intraoperative emotional state. ${ }^{27,29}$

\section{Follow-Up Assessment}

Only Humaidan et $\mathrm{al}^{26}$ followed up with abdominal pain 24 hours after leaving the clinic, once every six hours. Also, the 


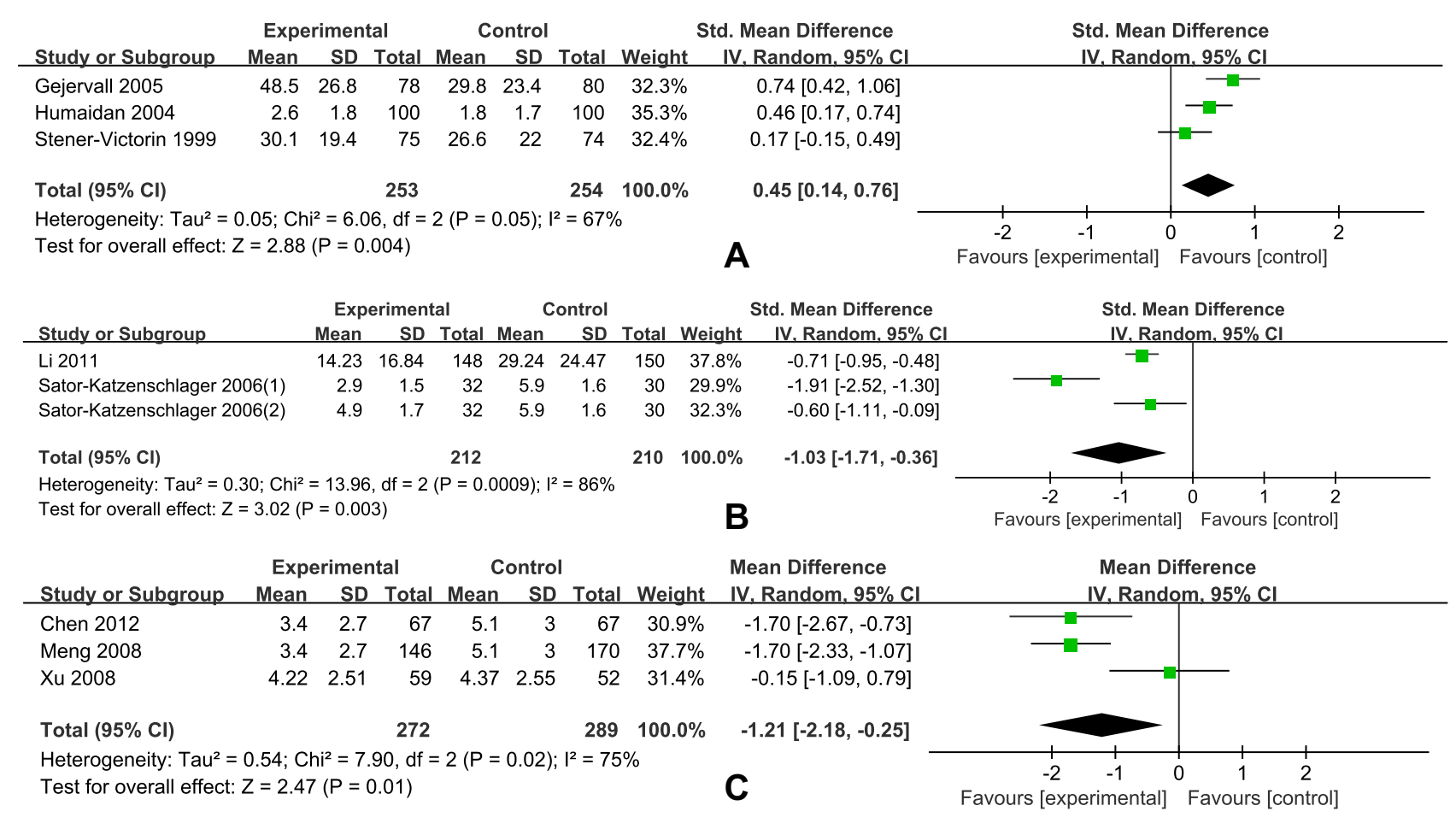

Figure 3 Forest plot for intraoperative pain of random effect model evaluated by simple self-rating scales. (A) Forest plot for intraoperative pain of random effect model evaluated by VAS (Electroacupuncture with PCB versus PCB with CSA). (B) Forest plot for intraoperative pain of random effect model evaluated by VAS (Acupuncture stimulation with CSA versus CSA). (C) Forest plot for intraoperative pain of random effect model evaluated by WHO pain rating scale (Electroacupuncture with CSA versus CSA).

pain of the observation group and the control group decreased 30 minutes after leaving the clinic, and there was no significant difference between the two groups $(\mathrm{P}>0.05)$.

\section{Operation Duration}

The operation duration was recorded in six studies. ${ }^{27,28,32,34-36}$ There was no significant difference between the experimental and control groups (see Table

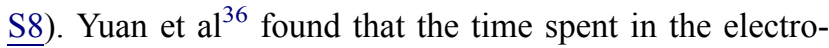
acupuncture combined with propofol group was shorter than propofol alone. EA combined with PCB treatment in Gejervall et al study ${ }^{27}$ took longer than premedication and alfentanil. Fan $^{35}$ and Wang ${ }^{32}$ conducted correlation analysis and found that there was no correlation between operation time and postoperative PRI, VAS, and PPI in the acupuncture group and the control group $(\mathrm{P}>0.05)$. Humaidan et $\mathrm{al}^{26}$ found that the outpatient time and cost of each OPU in the acupuncture group were significantly lower than those in the control group $(\mathrm{P}<0.001)$. Gejervall et $\mathrm{al}^{27}$ made an economic comparison between acupuncture and non-acupuncture, and found no significant difference in cost between the two groups $(P=0.718)$.

\section{$\beta$-Endorphin in Serum}

Three studies ${ }^{30,35,37}$ reported postoperative $\beta$-endorphin in serum. The intervention group of Fan's study ${ }^{35}$ and Tian et al study ${ }^{37}$ was significantly higher than the control group $(\mathrm{P}<0.05)$, and there was no difference in Kong's study $^{30}$ between the intervention group and the control group $(\mathrm{P}>0.05)$. See Table S9.

\section{Discussion}

\section{General Discussion of Main Results}

This review included 14 studies and investigated the analgesic effects of acupuncture in women during OPU through meta-analysis. Although previous reviews have examined several aspects of acupuncture analgesia, ${ }^{2,10,38}$ only one of these studies ${ }^{10}$ examined the analgesic effect of acupuncture-based during OPU limitedly. Other studies utilized acupuncture as an adjunctive therapy exploring analgesia for OPU. ${ }^{2,38}$ Compared to previous studies, we updated relevant studies to dates ${ }^{8,29-37}$ and selected more specific analytical measures. ${ }^{10}$ Finally, we included 14 studies with varied quality of individual studies separately. The overall sample size varies widely between studies, ranging from 60 to 409 , and only two studies ${ }^{28,37}$ reported 


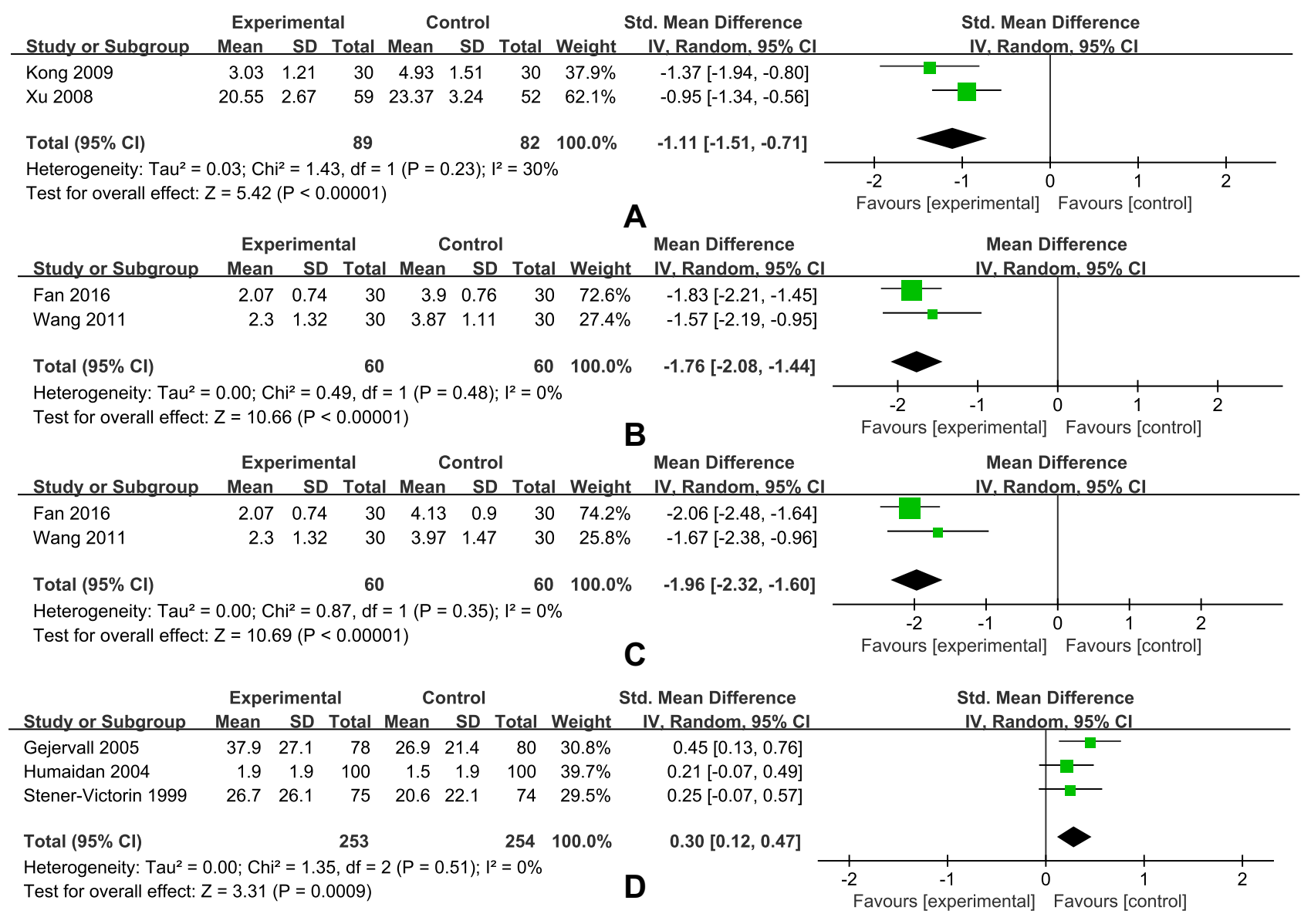

Figure 4 Forest plot for postoperative pain measured by simple self-rating scales. (A) Forest plot for postoperative pain of random effect model evaluated by VAS (Acupuncture stimulation with CSA versus CSA). (B) Forest plot for postoperative pain of random effect model evaluated by VAS (Acupuncture stimulation with NSAIDs versus sham acupuncture stimulation with NSAIDs). (C) Forest plot for postoperative pain of random effect model evaluated by VAS (Acupuncture stimulation with NSAIDs versus NSAIDs). (D) Forest plot for postoperative pain of random effect model evaluated by VAS (Electroacupuncture with PCB versus PCB with CSA).

blinded methods, which resulted in higher bias and heterogeneity.

Our findings were consistent with the previous studies ${ }^{2}$ that acupuncture combined with active analgesia showed better effects than single-strand analgesia. Acupuncture with CSA was more effective than CSA in intraoperative e,28,29,31,33 and postoperative $^{29,30}$ analgesia. Meanwhile, acupuncture with NSAIDs was more effective than sham acupuncture stimulation with NSAIDs (or NSAIDs alone). ${ }^{32,35}$ Regarding PPI and PRI scores at postoperative or one hour postoperatively, the acupuncture group (with or without the combination of other analgesic methods) in all three studies ${ }^{30,32,35}$ showed better analgesia than the control group. Besides, our findings suggested there was no significant analgesic advantage comparing electroacupuncture with PCB versus CSA with PCB, that there were no obvious analgesic advantages of the two interventions. In Stener-Victorin et al study, ${ }^{25}$ the analgesic effect of acupuncture combined with PCB was inferior to the analgesic effect of the combination of PCB and CSA. Noteworthy, participants in control groups in Gejervall et al study ${ }^{27}$ and Humaidan et al study ${ }^{26}$ received sedative pre-administration consisting of $0.5 \mathrm{mg}$ of oral flurazepam and $1 \mathrm{~g}$ of rectal paracetamol, or $10 \mathrm{mg}$ of benzodiazepines before intravenous injection of fentanyl and PCB. We cannot readily distinguish between anxiolytic, sedative, and analgesic effects because the preoperative medication might interfere to some extent with the ability to report pain experience.

In only one study, acupuncture was used as an independent analgesic. Tian et al conducted a large-sample study that proved that TEAS was more effective than mock TEAS. ${ }^{37}$ The number of oocytes retrieved and the related need for repeat aspirations directly affected the demand for analgesics. In this study, acupuncture could be independent and enough to relieve pain, possibly due to 


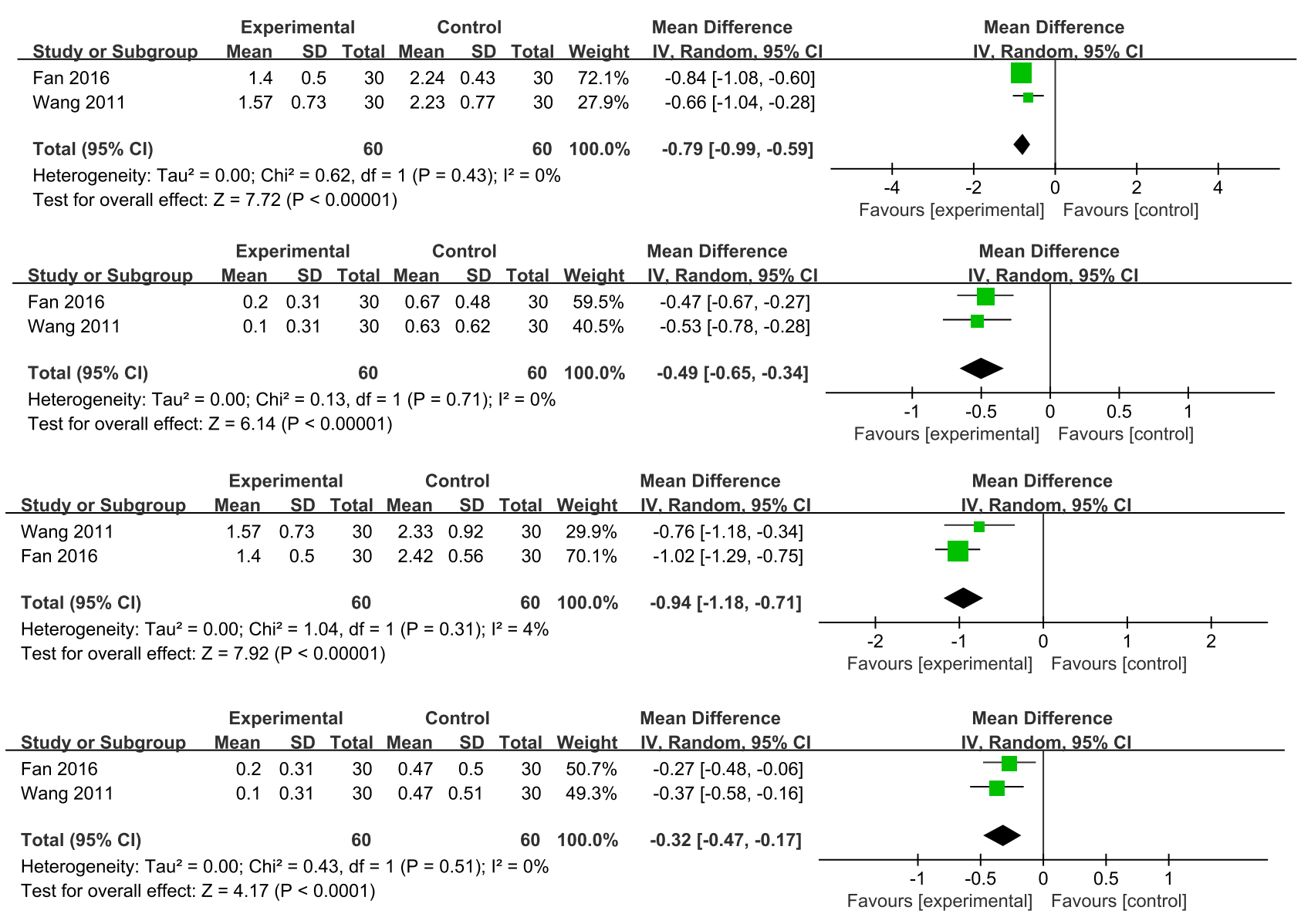

Figure 5 Forest plot for pain of random effect model evaluated by PPI. (A) Forest plot for pain directly after oocyte retrieval of random effect model evaluated by PPI (Acupuncture stimulation with NASIDs versus sham acupuncture stimulation with NASIDs). (B) Forest plot for pain one hour after oocyte retrieval of random effect model evaluated by PPI (Acupuncture stimulation with NASIDs versus sham acupuncture stimulation with NASIDs). (C) Forest plot for pain directly after oocyte retrieval of random effect model evaluated by PPI (Acupuncture stimulation with NASIDs versus NASIDs). (D) Forest plot for pain one hour after oocyte retrieval of random effect model evaluated by PPI (Acupuncture stimulation with NASIDs versus NASIDs).

the small number of eggs taken in the two groups (mean $<3$ ). Discomfort and pain during or after oocyte retrieval due to the several aspirations performed to obtain more oocytes. When more oocytes are retrieved, the ability of acupuncture to meet analgesia requires further exploration.

\section{Pain Assessments and Management}

Pain is a highly subjective and complex physiological and psychological activity, so subjective perception is the primary standard for evaluation. ${ }^{39,40}$ In surgical pain assessment, pain sensation should be reassessed several times depending on the type of procedure, adequacy of initial pain relief, side effects, presence of complications, and clinical status changes. ${ }^{40}$ The SMDs in pain on the simple self-rating scale (both VAS and WHO pain rating) between different acupuncture compound methods showed a clinical improvement in this review. ${ }^{8,28,29,31,33}$ Most of the studies used a one-dimensional scale pain assessment tool with fewer time points for pain assessment, and the percentage of pain reduction was not calculated. Therefore, data consolidation was complex, making it difficult to provide high-quality, evidence-based evidence. Threshold assessment may be an additional valuable tool based on individual variability, ${ }^{41}$ while biochemical markers that can be used to measure pain under stress, such as $\beta$-endorphin in serum and urinary CRF-LI concentrations, are also valuable. Still, only one study mentioned intraoperative threshold assessment, ${ }^{29}$ while three studies ${ }^{30,35,37}$ reported postoperative $\beta$-endorphin in serum.

\section{Advantages of Acupuncture for Analgesia}

Acupuncture is an appropriate option for women to avoid pharmacological anesthesia, including GA, PCB, CSA, which mainly produces postoperative adverse effects and potential effects on oocytes or embryos. Regional anesthesia has minimal effect on oocytes due 


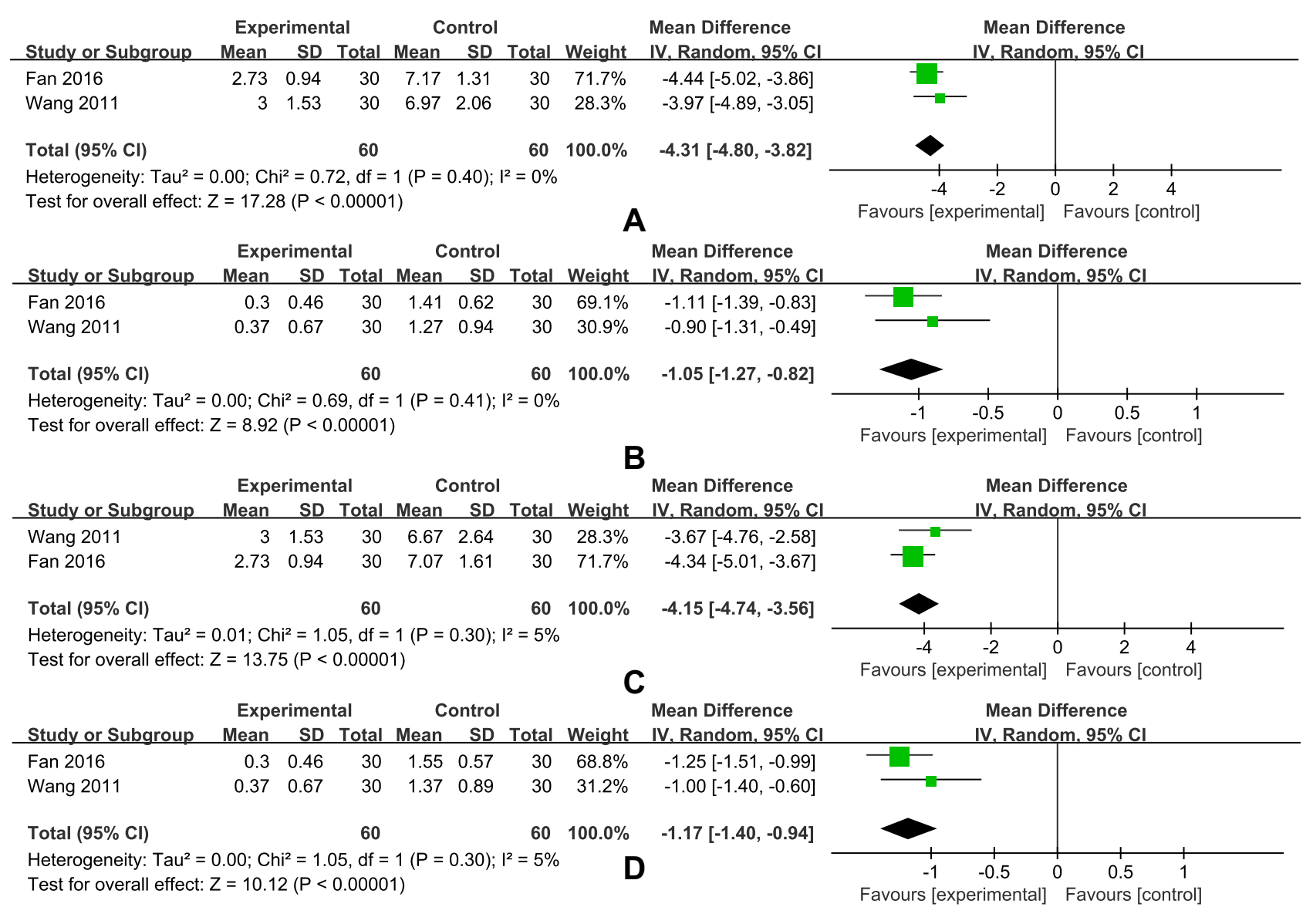

Figure 6 Forest plot for pain of random effect model evaluated by PRI. (A) Forest plot for pain directly after oocyte retrieval of random effect model evaluated by PRI (Acupuncture stimulation with NSAIDs versus sham acupuncture stimulation with NSAIDs). (B) Forest plot for pain one hour after oocyte retrieval of random effect model evaluated by PRI (Acupuncture stimulation with NSAIDs versus sham acupuncture stimulation with NSAIDs). (C) Forest plot for pain directly after oocyte retrieval of random effect model evaluated by PRI (Acupuncture stimulation with NSAIDs versus NSAIDs). (D) Forest plot for pain one hour after oocyte retrieval of random effect model evaluated by PRI (Acupuncture stimulation with NSAIDs versus NSAIDs.

to limited absorption in the circulation. ${ }^{42}$ Conversely, GA found in the follicular fluid may imply potential harms. ${ }^{43}$ Although the need for GA or non-invasive transvaginal OPU was decreased, the side effects of local anesthesia such as spinal headache, back pain, urinary retention, and significant nerve damage, and the inability to significantly meet the minimum requirements for analgesia have limited the potential use of local anesthesia. Propofol conscious sedation becomes a clear choice for OPU with rapid onset and recovery, adequate pain control, and no toxic side effects on the embryo and oocyte. Four studies ${ }^{8,29,33,36}$ included in this review indicated acupuncture combined with dolantin or propofol analgesia decreased adverse effects compared to using dolantin or propofol alone.

Over the years, acupuncture has become more widely recognized as having definitive efficacy in treating acute or chronic pain. ${ }^{44,45}$ This conventional therapy achieves pain intensity during OPU by suppressing the endogenous opioid system, increasing endogenous opioid peptide release, reducing inflammation, and improving uterine blood flow changes. ${ }^{6,46,47}$ In this review, $\operatorname{Fan}^{35}$ and Tian et $\mathrm{al}^{37}$ found significantly higher $\beta$-endorphin in the acupuncture group than the control groups $(\mathrm{P}<0.05)$. We also discovered that acupuncture is a safe analgesic approach since there were no differences between groups about the number of oocytes retrieved $27,28,30-32,34,35$ or clinical pregnancy $^{30-32,35,36}$ after the procedure.

\section{Limitations}

The review included a small number of studies with relatively low-quality evidence. Comparison of previous studies across trials was made difficult because acupuncture analgesia is often combined with other analgesic methods 
and by the lack of standard pain assessments. Indicators regarding the assessment, management of pain were not included in the study for discussion.

\section{Conclusions}

Acupuncture compound pharmacological anesthesia, which is more effective than a single form of pain relief, is worth promoting and safe. The quality of evidence regarding acupuncture alone as an analgesic is inadequate, and it is questionable whether minimal analgesia can be achieved. More high-quality trials need to be conducted to explore the analgesia of acupuncture for OPU in the future. The reduction in scores with the self-rated pain scales indicates a limitation in the improvement of symptoms. There should be more consensus and dimensionality in the assessment of pain. Individualized treatment and satisfaction assessment should also be considered in the management of pain.

\section{Abbreviations}

OPU, oocytes pick-up; ART, assisted reproductive technology; IVF, in vitro fertilization; GA, general anesthesia; PCB, paracervical block; CSA, conscious sedation and analgesia; RCTs, randomized controlled trials; PRISMA, Preferred Reporting Items for Systematic Reviews and Meta-analyses; TEAS, transcutaneous electrical acupoint stimulation; SF-MPQ, simplified McGill pain questionnaire; VAS, visual analog scale; WHO, World Health Organization; ORs, odds ratios; SMD, standardized mean difference; MD, mean difference; CIs, confidence Intervals; GRADE, Grading of Recommended Assessment Development and Evaluation; NSAIDs, nonsteroidal anti-inflammatory drugs; PPI, present pain intensity; PRI, pain rating index; NRS, numerical rating scale.

\section{Data Sharing Statement}

All the data was shown in the article.

\section{Ethics Approval}

Not applicable.

\section{Consent for Publication}

Written informed consent for publication was obtained from all participants.

\section{Funding}

This work was funded by the National Natural Science Foundation of China (grant number 81973966); Sichuan
Provincial Science and Technology Department Project (grant number 2020JDJQ0051); Clinical Research Center for Acupuncture and Moxibustion in Sichuan Province.

\section{Disclosure}

The authors report no conflicts of interest in this work.

\section{References}

1. Kwan I, Wang R, Pearce E, Bhattacharya S. Pain relief for women undergoing oocyte retrieval for assisted reproduction. Cochrane Database Syst Rev. 2018;7(1):5. doi:10.1186/s13643-018-0693-x

2. Hammarberg K, Wikland M, Nilsson L, Enk L. Patients' experience of transvaginal follicle aspiration under local anesthesia. Ann N Y Acad Sci. 1988;541:134-137. doi:10.1111/j.1749-6632.1988. tb22249.x

3. Beck R, Brizzi A, Cinnella G, Raimondo P, Kuczkowski KM. Anesthesia and analgesia for women undergoing oocyte retrieval. Pick Up Oocyte Manage. 2020.

4. Soussis I, Boyd O, Paraschos T, et al. Follicular fluid levels of midazolam, fentanyl, and alfentanil during transvaginal oocyte retrieval. Fertil Steril. 1995;64(5):1003-1007. doi:10.1016/S00150282(16)57919-9

5. Wikland M, Evers H, Jakobsson AH, Sandqvist U, Sjoblom P. The concentration of lidocaine in follicular fluid when used for paracervical block in a human IVF-ET programme. Hum Reprod. 1990;5 (8):920-923. doi:10.1093/oxfordjournals.humrep.a137220

6. Qiao L, Guo M, Qian J, Xu B, Gu C, Yang Y. Research advances on acupuncture analgesia. Am J Chin Med. 2020;48(2):245-258. doi:10.1142/S0192415X20500135

7. Chen T, Zhang WW, Chu YX, Wang YQ. Acupuncture for pain management: molecular mechanisms of action. Am J Chin Med. 2020;48(4):793-811. doi:10.1142/S0192415X20500408

8. Meng P, Wang LL, Xu B, Sun HX. [Application of acupuncture compound anesthesia in transvaginal ultrasound-guided oocyte retrieval]. Zhongguo Zhen Jiu. 2008;28(6):451-455. Chinese.

9. Xiang A, Cheng K, Shen X, Xu P, Liu S. The immediate analgesic effect of acupuncture for pain: a systematic review and meta-Analysis. Evid Based Complement Alternat Med. 2017;2017:3837194. doi:10.1155/2017/3837194

10. Stener-Victorin E. The pain-relieving effect of electroacupuncture and conventional medical analgesic methods during oocyte retrieval: a systematic review of randomized controlled trials. Hum Reprod. 2005;20(2):339-349. DOI:10.1093/humrep/deh595

11. Moher D, Liberati A, Tetzlaff J, Altman DG, Group P. Preferred reporting items for systematic reviews and meta-analyses: the PRISMA statement. J Clin Epidemiol. 2009;62(10):1006-1012. doi:10.1016/j.jclinepi.2009.06.005

12. Melzack R. The McGill Pain Questionnaire: major properties and scoring methods. Pain. 1975;1(3):277-299. doi:10.1016/03043959(75)90044-5

13. McCormack HM, Horne DJ, Sheather S. Clinical applications of visual analogue scales: a critical review. Psychol Med. 1988;18 (4):1007-1019. doi:10.1017/S0033291700009934

14. Higgins JPT, Green S Cochrane Handbook for Systematic Reviews of Interventions. Version 5.0.1 [updated September 2008]. The Cochrane Collaboration; 2008. Available from: http://www.cochranehandbook.org. Accessed March 30, 2018..

15. Guyatt GH, Oxman AD, Vist GE, et al. GRADE: an emerging consensus on rating quality of evidence and strength of recommendations. BMJ. 2008;336(7650):924-926. doi:10.1136/ bmj.39489.470347.AD 
16. Böhning D, Lerdsuwansri R, Holling H. Some general points on the measure of heterogeneity in meta-analysis. Metrika. 2017;80(68):685-695. doi:10.1007/s00184-017-0622-3

17. Higgins JP, Thompson SG, Deeks JJ, Altman DG. Measuring inconsistency in meta-analyses. BMJ. 2003;327(7414):557-560. doi:10.1136/bmj.327.7414.557

18. Sterne JA, Sutton AJ, Ioannidis JP, et al. Recommendations for examining and interpreting funnel plot asymmetry in meta-analyses of randomised controlled trials. BMJ. 2011;343:d4002. doi:10.1136/ bmj.d4002

19. Humaidan P. Pain relief during oocyte retrieval - exploring the role of different frequencies of electroacupuncture. Reprod Biomed Online. 2006;13(1):120-125. doi:10.1016/S1472-6483(10)62025-1

20. Zhang Y. Application of transcutaneous electrical nerve stimulation in postoperative analgesia. Smart Healthcare. 2021;7(5):85-86,89.

21. Zhang J, Wang X, Lü R. Analgesic effect of acupuncture at hegu (LI 4) on transvaginal oocyte retrieval with ultrasonography. J Tradit Chin Med. 2013;33(3):294-297. doi:10.1016/S0254-6272(13)60167-3

22. Zhang XY. The Clinical Study of Transcutaneous Electrical Acupoint Stimulation Analgesia During Oocyte Retrieval Operation in vitro Fertilization-Embryo Transfer (IVF-ET). Shandong University of TCM; 2014.

23. Ding W, Huang J A randomized controlled study on the analgesic effect of electroacupuncture at different auricular points on in vitro fertilization-embryo transfer egg retrieval. Proceedings of the 2015 Annual Meeting of the Chinese Society of Acupuncture and Moxibustion. Shanghai.

24. Cui SL, Li JY, Yu CY, et al. The role of electroacupuncture in in vitro fertilization for oocyte retrieval. Proceedings of the 2017 World Congress of Acupuncture and Moxibustion and the 2017 Annual Meeting of the Chinese Society of Acupuncture and Moxibustion. Beijing.

25. Stener-Victorin E, Waldenstrom U, Nilsson L, Wikland M, Janson PO. A prospective randomized study of electroacupuncture versus alfentanil as anaesthesia during oocyte aspiration in in-vitro fertilization. Hum Reprod. 1999;14(10):2480-2484. doi:10.1093/ humrep/14.10.2480

26. Humaidan P, Stener-Victorin E. Pain relief during oocyte retrieval with a new short duration electroacupuncture technique - an alternative to conventional analgesic methods. Hum Reprod. 2004;19 (6):1367-1372. doi:10.1093/humrep/deh229

27. Gejervall AL, Stener-Victorin E, Moller A, Janson PO, Werner C, Bergh C. Electroacupuncture versus conventional analgesia: a comparison of pain levels during oocyte aspiration and patients' experiences of well-being after surgery. Hum Reprod. 2005;20 (3):728-735. doi:10.1093/humrep/deh665

28. Sator-Katzenschlager SM, Wolfler MM, Kozek-Langenecker SA, et al. Auricular electroacupuncture as an additional perioperative analgesic method during oocyte aspiration in IVF treatment. Hum Reprod. 2006;21(8):2114-2120. doi:10.1093/humrep/del110

29. Xu JY. Clinical Observation on Efficacy of Analgesia for Electroacupuncture Interventional Therapy on Patients with Multiple Oocyte Aspiration Process of in vitro Fertilization and Embryo Transfer Training. Nanjing University of TCM; 2008.

30. Kong W. Application of Acupuncture Compound Anesthesia in Oocyte Retrieval Operation Undergoing in vitro FertilizationEmbryo Transfer. Shandong University of TCM; 2008.

31. Li N. A Clinical Study of Acupuncture Treatment in IVF-ET. Universuty of Lanzhou; 2011.
32. Wang XH. Application of Acupuncture Anethesia in IVF-ET Transvaginal Ultrasound-Guided Oocyte Retrieval. Shandong University of TCM; 2011.

33. Chen QQ, Wei QL, Zhang XH. [Effects of eletroacupuncture on supplementary analgesia and improvement of adverse reactions induced by dolant in oocyte retrieval]. Zhongguo Zhen Jiu. 2012;32 (12):1113-1116. Chinese.

34. Chen H, Wang YP, Xing JQ, et al. [Application of electroacupuncture at auricular points for analgesia in IVF-ET]. Jiangsu Med. 2015;41 (23):2863-2865. Chinese.

35. Fan K. Application of Auricular Analgesic Therapy in IVF-ET Transvaginal Ultrasound-Guided Oocyte Retrieval. Shandong University of TCM; 2016. Chinese.

36. Yuan H, Zhang LS, Wang N. [Evaluation of analgesic effect of acupuncture combined with electroacupuncture in IVF-ET]. J External Ther TCM. 2017;26(3):38-39. Chinese.

37. Tian L, Feng X, Zhang R, et al. Pain relief during oocyte retrieval by transcutaneous electrical acupoint stimulation: a single-blinded, randomized, controlled multicenter trial. Evid Based Complement Alternat Med. 2020;2020:3285648. doi:10. 1155/2020/3285648

38. Cheong YC, Dix S, Hung Y, Ng E, Ledger WL, Farquhar C. Acupuncture and assisted reproductive technology. Cochrane $\mathrm{Db}$ Syst Rev. 2013;7. doi:10.1002/14651858.CD006920.pub3

39. Hjermstad MJ, Fayers PM, Haugen DF, et al. Studies comparing Numerical Rating Scales, Verbal Rating Scales, and Visual Analogue Scales for assessment of pain intensity in adults: a systematic literature review. J Pain Symptom Manage. 2011;41 (6):1073-1093. doi:10.1016/j.jpainsymman.2010.08.016

40. Gordon DB. Acute pain assessment tools: let us move beyond simple pain ratings. Curr Opin Anaesthesiol. 2015;28(5):565-569. doi:10.1097/ACO.0000000000000225

41. Lund I, Lundeberg T. Aspects of pain, its assessment and evaluation from an acupuncture perspective. Acupunct Med. 2006;24 (3):109-117. doi:10.1136/aim.24.3.109

42. Kogosowski A, Lessing JB, Amit A, Rudick V, Peyser MR, David MP. Epidural block: a preferred method of anesthesia for ultrasonically guided oocyte retrieval. Fertil Steril. 1987;47 (1):166-168. doi:10.1016/S0015-0282(16)49954-1

43. Guasch E, Gómez R, Brogly N, Gilsanz F. Anesthesia and analgesia for transvaginal oocyte retrieval. Should we recommend or avoid any anesthetic drug or technique? Curr Opin Anaesthesiol. 2019;32 (3):285-290. doi:10.1097/ACO.0000000000000715

44. Vickers AJ, Vertosick EA, Lewith G, et al. Acupuncture for Chronic Pain: update of an individual patient data meta-analysis. J Pain. 2018;19(5):455-474. doi:10.1016/j.jpain.2017.11.005

45. Jan AL, Aldridge ES, Rogers IR, Visser EJ, Bulsara MK, Niemtzow RC. Does acupuncture have a role in providing analgesia in the emergency setting? a systematic review and meta-analysis. Emerg Med Australas. 2017;29(5):490-498. doi:10.1111/17426723.12832

46. Han JS. Acupuncture: neuropeptide release produced by electrical stimulation of different frequencies. Trends Neurosci. 2003;26 (1):17-22. doi:10.1016/S0166-2236(02)00006-1

47. Erthal V, da Silva MD, Cidral-Filho FJ, Santos AR, Nohama P. ST36 laser acupuncture reduces pain-related behavior in rats: involvement of the opioidergic and serotonergic systems. Lasers Med Sci. 2013;28 (5):1345-1351. doi:10.1007/s10103-012-1260-7 


\section{Publish your work in this journal}

The Journal of Pain Research is an international, peer reviewed, open access, online journal that welcomes laboratory and clinical findings in the fields of pain research and the prevention and management of pain. Original research, reviews, symposium reports, hypothesis formation and commentaries are all considered for publication. The manuscript

Submit your manuscript here: https://www.dovepress.com/journal-of-pain-research-journal management system is completely online and includes a very quick and fair peer-review system, which is all easy to use. Visit http:// www.dovepress.com/testimonials.php to read real quotes from published authors. 